http://dx.doi.org/10.15762/ZH.2017.65

WALDEMAR ROZYNKOWSKI

(Nicolaus Copernicus University in Toruń)

\title{
Priest StanisŁaW Kujot AS A Clergyman
}

Key words: clergymen of the Chelmno diocese, the $19^{\text {th }}$ century, the Scientific Society in Torun, the parish church of St. Nicholas in Gniew, Collegium Marianum in Peplin, the parish church in Grzybno, the Chelmno diocese

\section{INTRODUCTION}

On 10 April 1870 a deacon Stanisław Kujot was ordained a priest in the Cathedral of Pelplin. ${ }^{1}$ This means that any study about his life will need to encompass his pastoral activities. Let us highlight at this point that we may be able to find threads of his ministerial service in different forms of his activity. It can be generally stated that whatever he did after his ordination was related to his priesthood. He was a teacher, a historian, man of letters, president of the Scientific Society in Torun, and a priest. At the same time we are aware that priestly service has its own characteristics, such as administering sacraments or performing ecclesiastical functions which are reserved only for priests, e.g. the function of a vicar or a parish priest. Let us review a few chapters in the priestly activity of Rev. S. Kujot.

It is worth noting that the aspect of Rev. Kujot's life undertaken in this article has been practically left out by all the research on the issue to date. ${ }^{2}$ It is justifi-

${ }^{1}$ Henryk Mross, Stownik biograficzny kapłanów diecezji chetmińskiej wyświęconych $w$ latach 1821-1920, Pelplin 1995, p. 157.

${ }^{2}$ The most complete cross-sectional description of the figure of Stanisław Kujot so far has been prepared by Kazimierz JAsı́́ski, Stanisław Kujot (1845-1914), [in:] Działacze Towarzystwa Naukowego w Toruniu, ed. Marian BISKup, Toruń 1975, pp. 85-179. The characteristics of the priest's scientific and literary activity in: Jan WALKusz, Piórem i słowem. Aktywność literacka polskiego duchowieństwa katolickiego na Pomorzu Nadwiślańskim, Warmii i w Wielkopolsce w latach 1848-1939, Pelplin 2003, passim; idem, „Gdyby o Polskę pytali...”. Z dziejów duchowieństwa Pomorza i Wielkopolski w XIX i XX wieku, Lublin 2004, passim; Dariusz Aleksander DeKAŃskI, Polskie środowisko toruńsko-pelplińskich mediewistów XIX i początku XX wieku. Najwybitniejsi przedstawiciele. Kierunki badań. Ośrodek naukowy, Gdańsk 2009, pp. 83-120. 
able to a degree. Why? The reason is that the proper source documentation is missing. When looking for the information about priestly service of Rev. S. Kujot we must rely on the scant information dispersed in the source texts. It should be mentioned here that the state of affairs quoted here is not only typical of the life of Rev. S. Kujot. One may say that we are referring to a certain specificity of research into ministerial service of priests. At the same time it must be highlighted that we have at our disposal one important group of source texts which are essential for studies over ministerial service, namely parish register materials. The use of such source materials contributes greatly to collecting many important information about the ministerial service of Rev. S. Kujot.

When Rev. Tadeusz Glemma was concluding his research into the Diocese of Chełmno, his first words concerning Rev. S. Kujot were as follows: "X. Stanisław Kujot, undoubtedly the most meritorious person in the historiography of the Diocese of Chełmno, and at the same time distinguished pastor and expert educator". ${ }^{3}$ Paweł Czaplewski, on the other hand, when reminiscing about late Rev. S. Kujot in the text published in the Records of the Scientific Society in Torun starts with the words: "A priest and a man of letters, a eulogist of prayer and work, president of the Scientific Society in Toruń, parish priest in Grzybno". ${ }^{4}$

As can be seen in the extracts above, by making a short summary of Rev. S. Kujot's life and achievements, the authors also related to his religious side by referring to him as a distinguished pastor, eulogist of prayer and parish priest in Grzybno.

Undoubtedly, Rev. S Kujot is associated with his historical, literary and didactic achievements, but not with ministerial service. Perhaps the circumstances of his Presbyterian ordination were the harbinger of his future priesthood. As mentioned before, he was ordained on 10 April 1870. However, it should be noted that it was exactly during his holiday break from his studies in Berlin. The circumstances of the ordainment of other deacons in the Diocese of Chełmno in the second half of the $19^{\text {th }}$ century must have been completely different. Besides, when the neo-presbyters went on to exercise their ministerial services after the ordainment, he returned to Berlin to continue his studies. In autumn that year he went to Münster, where on 27 January 1872 he passed the state examination. ${ }^{5} \mathrm{He}$ returned to the Diocese of Chełmno only after this event.

${ }^{3}$ Tadeusz Glemma, Historjografja diecezji chełmińskiej aż po rok 1821 (Nowa Polonia Sacra, vol. 2), Kraków 1926, p. 55.

${ }^{4}$ Paweł Czaplewski, Ś.p. Ks. Stanisław Kujot, Zapiski Towarzystwa Naukowego w Toruniu, vol. 3: 1914-1915, p. 49.

${ }^{5}$ K. JAsIŃsKI, op.cit., p. 91. 


\section{VICAR IN GNIEW}

Having graduated from his studies, perhaps as early as in February 1872, Rev. S. Kujot returned to the Diocese of Chełmno. The first facility of his vicarial service was the parish of St. Nicholas in Gniew. It seems that the assumption was that his presence there was to be short-lived and that he was intended to work at the Collegium Marianum in Pelplin.

Gniew parish register books preserved in the Diocese Archive in Pelplin contain annotations about Rev. S. Kujot being a dispenser of the sacrament of baptism. During his stay in Gniew for several months he dispensed the sacrament of baptism 29 times, mostly in April, May and June. His activity in that area is disrupted at the end of September that year. That year the total of 227 baptisms were dispensed in the parish of Gniew. ${ }^{6}$ It seems that in the course of his service as a vicar, which lasted several months, Rev. S. Kujot was actively taking part in ministerial service, at least as far as baptism is concerned. Rev. S. Kujot solemnised only one marriage. It took place exactly on 13 May $1872 .{ }^{7}$

From the perspective of Rev. S. Kujot's entire life the period of vicariate was but a short episode. Perhaps for himself it was not time of great significance. This could be corroborated by the fact that one of his preserved autobiographies does not contain any mentions of his stay in Gniew. ${ }^{8}$

\section{Teacher at Collegium Marianum in Pelplin}

In all likelihood, from the end of September 1872 Rev. S Kujot was in Pelplin. For over 21 years - until March 1893 - he occupied the post of a teacher at the bishops' gymnasium (grammar school) called Collegium Marianum. ${ }^{9}$ There, he ran classes in general history and the history of Polish literature.

It is difficult, even in the form of an outline, to define this period from the perspective of Rev. S. Kujot's ministerial service. Yet, it was a period in his life that was long enough (over twenty years) for us to find some of his ministerial activity in Pelplin. We have no doubts that when he worked as a teacher, his students perceived him also as a priest. It is difficult to say whether he was exercising priestly services towards his students. It can be assumed that he celebrated liturgy for the students together with other priests in the school chapel. After Rev. S. Kujot died, Rev. Paweł Czaplewski wrote in an article that: "he was the most frequent visitor

${ }^{6}$ Archiwum Diecezjalne w Pelplinie [Diocese Archive in Pelplin], księgi metrykalne parafii w Gniewie [Gniew parish register], files no. W 945, no. 51, 69-71, 83-84, 86-89, 91, 93, 95-98, 100-102, 117, 124, 133-134, 137, 143, 147, 154, 158-159.

${ }^{7}$ Ibid., księgi metrykalne parafii w Gniewie, księgi małżeństw [Register Book of Marriages], 13 May 1872.

${ }^{8}$ K. JAsińsKI, op.cit., p. 95, footnote 35.

${ }_{9}^{9}$ Paweł Czaplewski, Collegium Marianum 1836-1936. Na stuletnia rocznice, Pelplin 1936, p. 17. 
in the school chapel, a source of grace and all strength" ${ }^{10}$ It is difficult to interpret those words, but it appears that they were not only courteous flattery, but they referred to the actual priestly image of Rev. S. Kujot.

One of S. Kujot's students at the Collegium was Franciszek Sawicki, a future priest and a renowned philosopher. He reminisced about his professor saying: "School requirements were strict and the students competed among each other, which allowed them to develop their talents. In such atmosphere religion gave me a new vital strength which captivated my entire soul. I was impressed the most by the preparatory classes with the unforgettable Kujot together with the sacraments of penance and altar".

When analysing the ministerial service of Rev. S. Kujot in the Pelplin period it must be noted that his service was exercised in Catholic organisations. He occupied the post of a cashier (treasurer) at the diocese association of St. Boniface and St. Wojciech, served the sick in St. Joseph's Home and became president of St. Vincent's association in Pelplin, according to Rev. Paweł Czaplewski. ${ }^{12}$

The literature dedicated to Rev. S. Kujot mentions one more dimension of his ministerial service. In his Pelplin period he would go to different religious celebrations, and asked to give indulgence and funeral sermons. ${ }^{13}$ This information deserves to be extended and verified indeed. However, we may assume that during his time spent at Collegium Marianum, without the necessity to perform parish duties, he was at liberty to accept numerous invitations to different religious events. However, we need to conduct a more detailed search in the dispersed source materials, which will demonstrate a true scale of the phenomenon.

\section{PARISH PRIEST IN GRZYBNO}

On 23 March 1893 Rev. S. Kujot took over the administration over the parish in Grzybno. ${ }^{14}$ The origins of the parish go back to the Middle Ages. It was established at the beginning of the $14^{\text {th }}$ century. ${ }^{15}$ As far as the ecclesiastical administrative division is concerned, from the medieval times it had been part of the Diocese of Chełmno and Deanery of Chełmża. ${ }^{16}$ In the year when Rev. S. Kujot took over the parish it numbered 1366 parishioners. ${ }^{17}$ At the beginning of the

${ }^{10}$ Idem, S.p. Ks. Stanisław Kujot, p. 53.

${ }^{11}$ Idem, Collegium Marianum, p. 22.

${ }^{12}$ Idem, S.p. Ks. Stanisław Kujot, p. 53.

${ }^{13}$ Ibid.; K. JAsIŃsKI, op.cit., p. 104.

${ }^{14}$ Schematismus des Bisthums Culm mit der Bischofsitze in Pelplin 1904, Pelplin 1904, p. 89.

${ }^{15}$ Waldemar Rozynkowski, Powstanie i rozwój sieci parafialnej $w$ diecezji chetmińskiej w czasach panowania zakonu krzyżackiego, Toruń 2000, p. 147.

${ }^{16}$ Bogusław DygdaŁA, Struktury parafialne diecezji chetmińskiej w XVII-XVIII wieku, Toruń 2009, pp. 330-332, 336-339.

${ }^{17}$ Directorium Divini Officii et Missarum in usum Universi Cleri Dioecesis Culmensis, Gedani 1894, p. 54. 
$20^{\text {th }}$ century, and more precisely in 1904, the parish numbered 1426 parishioners, 875 of whom could receive Holy Communion. Let us note that the filial church in Trzebcz, which belonged to the parish, extended over about a half of the parishioners. ${ }^{18}$ Summing up the cited figures, we may conclude that the parish in Grzybno was rather sizable. It means that the new parish priest was facing some new ministerial challenges. By analysing the entries in the parish register, there were a lot of them. At first he tackled them on his own, but after a few years he was assisted by vicars. Further on in this paper we will demonstrate that the demand for their assistance was increasing.

As it was noted by $\mathrm{K}$. Jasiński, assuming the function of a parish priest meant that for more or less a year his work as a researcher was put on hold. K. Jasiński cited an interesting letter of the new parish priest from Grzybno to a historian, Rev. Jan Fjałek of 24 June 1893. Three months after taking up the new post he wrote: "Weeks of tedious office work have started for me now that I have been moved to the parish. My new job involves writing official correspondence and sorting out old bills [...]. Well, yesterday, at last, I finished digging in the figures for the incense I bought, etc.". ${ }^{19}$ It appears that the priest had to take up a role that was completely new for him. Part of that new reality was the necessity to run administration and care about material matters, which was an important element of running the parish.

The life of Rev. S. Kujot changed in many respects after he had moved to the parish in Grzybno. When the priest was staying in Pelplin, he was leading a very active life. He would often travel from his place of work to visit his family, to health resorts or places where he collected materials to his works. In the Grzybno period, he left the parish much less frequently, especially from 1903 . The reason for this was the excess of parish responsibilities, and also a sickness, which progressively damaged the priest's body, and in a way marked the entire ministerial service and the activity of Rev. S. Kujot during his stay in Grzybno. ${ }^{20}$

We cannot exclude the possibility that he was considering an early retirement on account of his health condition. In a letter to Władysław Chotkowski of 31 March 1896 he wrote: "My lungs are weak and if I cannot cope anymore, I will retire, with a pension of about 500 marks, I'll sell the horses and carts and sneak out to Cracow to work in the quietude of libraries.". ${ }^{21}$ It is difficult to judge today whether they were serious plans or just loose thoughts. However, it is beyond any doubts that his ministerial capability, as well as other undertaken activities

\footnotetext{
${ }^{18}$ Schematismus des Bisthums Culm, pp. 88-89.

${ }^{19}$ K. JAsińsKi, op.cit., p. 98, footnote 62.

${ }^{20}$ See ibid., p. 104.

${ }^{21}$ Ibid., p. 99.
} 
during his stay in Grzybno, until his death, would be marked by the condition of his health.

Kazimierz Jasiński suggests that Rev. S. Kujot remained in the parish in Grzybno in spite of his deteriorating health, because in 1897 he was appointed to be the president of the Scientific Association in Torun, which had been just reactivated..$^{22}$ Bold as this hypothesis may appear, it is rather probable.

Some of the aspects of Rev. S. Kujot's ministerial service during his period as the parish priest in Grzybno can be presented in detail. As it was noted in the introduction, the ministerial service of Rev. Kujot can be analysed from the perspective of the sacraments that he dispensed, as well as celebrating funeral liturgy. The archive of the parish in Grzybno contains two parish register books from the period of his service. The records in question are the book of baptism from the period 1892-1957 and the book of marriages from the years 1876-1939. The Archive of Historical Acts of the Diocese of Torun contains the book of the deceased from the period 1869-1907. The entries contained in the books allow us to follow the tracks of Rev. S. Kujot's ministerial service in the context of dispensing sacraments of baptism, celebrating marriages and burying the dead.

Probably the first entry to the parish register made by Rev. S. Kujot related to a funeral. He made all the necessary annotations on 20 April $1893 .{ }^{23} \mathrm{His}$ first entry in the book of baptisms can be found with the date of 13 July $1893 .^{24}$

The following is a list of baptisms, marriages and funerals in the parish of Grzybno in the period when Rev. S. Kujot was a parish priest. The first number on the list refers to the service celebrated by the parish priest. The second number refers to the number of all services in the parish.

Tab. List of baptisms, marriages and funerals in the parish of Grzybno in the period 1893-1914

\begin{tabular}{|r|r|r|c|}
\hline Year & Baptism & Wedding & Funeral $^{\star}$ \\
\hline $\mathbf{1 8 9 3}$ & 41 per 41 & 4 per 6 & 24 per $24^{\text {** }}$ \\
\hline $\mathbf{1 8 9 4}$ & 68 per 69 & 16 per 18 & 47 per 47 \\
\hline $\mathbf{1 8 9 5}$ & 50 per 65 & 10 per 10 & 38 per 41 \\
\hline $\mathbf{1 8 9 6}$ & 82 per 82 & 12 per 13 & 32 per 32 \\
\hline
\end{tabular}

${ }^{22}$ Ibid.

${ }^{23}$ Archiwum Akt Dawnych Diecezji Toruńskiej w Toruniu [The Archive of Historical Acts of the Diocese of Toruń], Katalog ksiąg metrykalnych parafii diecezji toruńskiej [a catalogue of parish register books of the Diocese of Toruń], Parafia pw. Św. Michała Archanioła w Grzybnie [Parish church of St. Archangel Michael in Grzybno], file no. AE 002, Liber mortuorum 1869-1907, year 1893, no. 6 .

${ }^{24}$ Archiwum parafii w Grzybnie [Archive of the parish in Grzybno], Księga ochrzczonych [Book of baptisms], year 1893, no. 28, fol. 3 . 


\begin{tabular}{|c|c|c|c|}
\hline 1897 & 53 per 55 & 7 per 8 & 30 per 34 \\
\hline 1898 & 18 per 69 & 3 per 13 & 15 per 30 \\
\hline 1899 & 24 per 78 & 4 per 9 & 30 per 31 \\
\hline 1900 & 25 per 68 & 6 per 17 & 35 per 35 \\
\hline 1901 & 24 per 60 & 4 per 9 & 34 per 34 \\
\hline 1902 & 32 per 62 & 7 per 13 & 26 per 40 \\
\hline 1903 & 20 per 78 & 2 per 12 & 36 per 40 \\
\hline 1904 & 22 per 45 & 2 per 10 & 27 per 31 \\
\hline 1905 & 37 per 67 & 6 per 15 & 38 per 38 \\
\hline 1906 & 25 per 74 & 7 per 18 & 33 per 33 \\
\hline 1907 & 5 per 61 & 1 per 13 & 31 per 31 \\
\hline 1908 & 4 per 63 & 0 per 6 & - \\
\hline 1909 & 4 per 56 & 0 per 11 & - \\
\hline 1910 & 2 per 62 & 1 per 14 & - \\
\hline 1911 & 1 per 48 & 0 per 15 & - \\
\hline 1912 & 3 per 48 & 0 per 15 & - \\
\hline 1913 & 3 per 56 & 1 per 18 & - \\
\hline $1914^{\star \star \star \star}$ & 0 per 26 & 0 per 3 & - \\
\hline
\end{tabular}

* In some cases funerals were held outside the parish in Grzybno. Rev. S. Kujot made appropriate annotations in the book of the deceased.

${ }^{* *}$ In 1893, the total of 29 funerals were recorded, 5 of which were held prior to the arrival of Rev. S. Kujot.

*** The list includes the entries up to the day of Rev. S. Kujot's death on 5 December 1914.

Source: Archiwum Akt Dawnych Diecezji Toruńskiej w Toruniu [The Archive of Historical Acts of the Diocese of Toruń], Katalog ksiąg metykalnych parafii diecezji toruńskiej [a catalogue of parish register books of the Diocese of Toruń], Parafia pw. Św. Michała Archanioła w Grzybnie [Parish church of St. Archangel Michael in Grzybno], file no. AE 002, Liber mortuorum 1869-1907; Archiwum parafii w Grzybnie [Archive of the parish in Grzybno], Księga ochrzczonych [Book of baptisms] 1892-1957; Księga małżeństw [Book of marriages] 1876-1939.

The numerical data presented in the figure allows a number of interesting conclusions. As shown in the table, in the first years of his stay in the parish, Rev. S. Kujot was the only one to dispense the sacrament of baptism, celebrate marriages and lead funerals. He was a dedicated clergyman. The books contain only occasional entries of other priests who assisted the Rev. Kujot in Grzybno. They included a vicar from Unisław, Władysław Szafrański (1894) and Rev. Jan Burtschik (1897). In 1895 the parish was assisted also by Rev. Bolesław Domański. This is indicated by several entries in the book of baptisms. It is likely that he stayed in the parish for some time. ${ }^{25}$

${ }^{25}$ See H. Mross, op.cit., pp. 53-55. 
A few years of unaided service (sometimes with the assistance of other priests from neighbouring parishes) made Rev. S. Kujot take efforts to engage a vicar. Their presence in the parish can be traced from 1898. This is demonstrated by the numerical data in the table above. From that year on, it was the vicars who dispensed sacraments more often. According to the entries in the book of baptisms they included (in the order of chronology) Rev. Adam Lorenz (1898), Rev. Teodor Maćkowski (1899), Rev. Jan Czaplewski (1899-1900), Rev. Tomasz Gosk (1900-1901), Rev. Antoni Bielski (1901-1904), Rev. Paweł Nagórski (1905), Rev. Leon Połomski (1905-1906), Rev. Marceli Doroszyński (1906), Rev. Kazimierz Chmielecki (1906-1909), Rev. Józef Wilemski (1909) and Rev. Cyryl Karczyński (1909-1915), who played the role of a parish administrator for some time after S. Kujot's death.

Interestingly, Rev. S. Kujot engaged some of the vicars in the affairs of the Scientific Society in Torun. For example, Rev. Kazimierz Chmielecki and Rev. Cyryl Karczyński occupied the post of the Society's treasurers. ${ }^{26}$ The latter was also involved in the works for the collection of relics of folk art, especially folk songs. ${ }^{27}$

We know that in the times of Rev. S. Kujot two communities that associated lay parishioners were created: The Apostolate of Prayer (the establishing document was issued on 14 December 1894, active until 7 January 1895) and the Brotherhood of Sobriety (from December 1895). ${ }^{28}$ As can be seen, both groups were established soon after the new parish priest's arrival. It is likely that their presence in the parish was a direct initiative of Rev. S. Kujot, perhaps related to some religious events, e.g. parish missions.

To complete the description of Rev. S. Kujot's image it should be noted that in the period 1897-1899 he occupied the post of Dean of Chełmża. ${ }^{29}$ He replaced Rev. Antoni Kamiński, the parish priest of Chełmża. ${ }^{30} \mathrm{He}$ was followed on this post by the parish priest of Papowo, Rev. Józef Poeplau. ${ }^{31}$

Rev. S. Kujot's health deteriorated in the second half of $1906 .{ }^{32}$ This is confirmed by the numerical data shown in the table above. It is clear that he found it increasingly difficult to perform his ministerial duties. In a letter to Rev. Mieczysław Rzewuski of 18 December 1906 he shared what his health condition was like: "I sent a quick note to Pelplin asking for permission to celebrate in the par-

${ }^{26}$ K. JASIŃSKI, op.cit., pp. $133-134$.

${ }^{27}$ H. Mross, op.cit., pp. 125-126.

${ }^{28}$ Schematismus des Bisthums Culm, p. 88.

${ }^{29}$ K. JAsIŃsKI, op.cit., pp. 99-100, 105; H. Mross, op.cit., p. 395.

${ }^{30}$ Ryszard MuzioŁ, Słownik biograficzny Chetmży i okolic, vol. 2, Chełmża 2014, p. 41.

${ }^{31}$ H. Mross, op.cit., p. 395; Waldemar Rozynkowski, Szkice $z$ dziejów gminy Papowo Biskupie, Toruń 2014, pp. 55-56.

${ }^{32} \mathrm{~K}$. JASIŃsKI, op.cit., p. 105. 
ish (and to Rome). I'm afraid they might accuse me of haste". ${ }^{33}$ We know that ecclesiastical authorities would have acceded to Rev. Kujot's request. When at the beginning of 1911 he invited doctor Otton Steinborn to Grzybno he wrote: "I hould not speak and I cannot. If the guest allows, I will answer his questions in writing. This is how we will communicate" ${ }^{34}$

The following months brought further deterioration of his health. Rev. S. Kujot was less and less present in the active life of the parish. He died on 5 December 1914 in the parish in Grzybno at the age of 69. He was buried on the parish cemetery right next to the church on 9 December. ${ }^{35}$

\section{ConClusion}

The description of ministerial service of Rev. S. Kujot demonstrated in this article reveals those motifs of life of this famous historian, man of letters and educator, that have been little known so far. Although the undertaken task has not been fully exhausted, several important aspects of his ministerial service have been indicated. We have no doubt that the most important ministerial activity of Rev. S. Kujot was related to his service in the parish of Grzybno. It appears that it was chiefly his stay in this parish, that emphasised or even endowed him with a distinct ministerial identity.

It should be noted that when he published his most important work Kto zało$\dot{z} y$ t parafie $w$ dzisiejszej dyecezyi chetminskiej? he signed on the page cover with the following inscription: "Rev. Stanisław Kujot, Parish Priest in Grzybno, Unisław Post Office". Kazimierz Jasiński notes that in his correspondence he added the words "parish priest in Grzybno" next to his name and surname very often. ${ }^{36}$
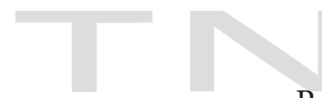

(trans. by Tomasz Leszczuk)

Received $15^{\text {th }}$ December 2016

Received in revised form $2^{\text {nd }}$ May 2017

Accepted 26 ${ }^{\text {th }}$ May 2017

Prof. dr hab. Waldemar Rozynkowski

Institute of History and Archival Studies

Nicolaus Copernicus University in Torun

e-mail:wr@umk.pl

\footnotetext{
${ }^{33}$ Cyt. za: ibid., pp. $99-100$, p. 68.

${ }^{34}$ Quote: ibid., p. 106.

${ }^{35}$ H. Mross, op.cit., p. 158.

${ }^{36}$ K. JAsIŃsKI, op.cit., p. 85, p. 1.
} 


\section{Summary}

Key words: clergymen of the Chełmno diocese, the $19^{\text {th }}$ century, the Scientific Society in Toruń, the parish church of St. Nicholas in Gniew, Collegium Marianum in Peplin, the parish church in Grzybno, the Chełmno diocese

On 10 April 1870 a deacon Stanisław Kujot was ordained priest in the cathedral in Pelplin. It means that one of the challenges in the research on his life is the question about the activity of this clergyman. So far this question has been addressed marginally, which is partly understood since the scarce information about the priest can be found only in scattered sources. However, the article refers to a very important group of sources - parish registers.

The description of the service of the priest Stanisław Kujot reveals new pieces of information about him, which are connected with his stay in such places as the parish church of St. Nicholas in Gniew, Collegium Marianum in Pelplin and the parish church in Grzybno. The most important period were the years 1893-1914 when he worked as a parish priest in Grzybno.

\section{Pfarrer StanisŁaw Kujot als Seelsorger \\ Zusammenfassung}

Schlüsselwörter: Klerus des Bistums Thorn, 19. Jahrhundert, Wissenschaftliche Gesellschaft in Thorn, Pfarrei St. Nikolaus in Mewe (Gniew), Collegium Marianum in Pelplin, Pfarrei in Griebenau (Grzybno), Bistum Kulm

Am 10. April 1870 wurde der Diakon Stanisław Kujot in der Kathedrale von Pelplin zum Priester geweiht. Mithin ist eine der Herausforderungen bei Forschungen zu seinem Leben die Frage nach der seelsorgerlichen Tätigkeit dieses Priesters. In den bisherigen Untersuchungen zum Leben von Pfarrer Kujot ist diese Problematik nur am Rande aufgegriffen worden. Das ist zum Teil verständlich, denn bei der Suche nach Informationen über den seelsorgerlichen Dienst von Pfarrer Kujot sind wir meistens auf die spärlichen Informationen angewiesen, die sich im verstreuten Quellenmaterial finden. Der Artikel stützt sich aber auf eine sehr wichtige Quellengruppe, nämlich auf Kirchenbücher.

Die Beschreibung des seelsorglichen Dienstes von Pfarrer Kujot zeigt uns wenig bekannte Seiten aus dem Leben dieses Priesters. Sie handelt von seiner Tätigkeit an Orten wie der Pfarrei Sankt Nikolaus in Mewe (Gniew), dem Kollegium Marianum in Pelplin und der Pfarrei in Griebenau (Grzybno). Das seelsorgerliche Profil von Pfarrer Kujot war vor allem von seinem priesterlichen Dienst in den Jahren 1893-1914 in der Pfarrei in Griebenau geprägt. 


\section{BIBLIOGRAPHY}

Czaplewski, Paweł. „Ś. p. Ks. Stanisław Kujot”. Zapiski Towarzystwa Naukowego w Toruniu 3, no. 4/5 (1914/1915): 49-67.

Czaplewski, Paweł. Collegium Marianum 1836-1936. Na stuletnia rocznicę. Pelplin: Collegium Marianum, 1936.

Dekański, Dariusz A. Polskie środowisko toruńsko-pelplińskich mediewistów XIX i początku XX wieku. Najwybitniejsi przedstawiciele. Kierunki badań. Ośrodek naukowy. Gdańsk: Wydawnictwo Uniwersytetu Gdańskiego, 2009.

Dygdała, Bogusław. Struktury parafialne diecezji chełmińskiej w XVII-XVIII wieku. Torun: TNT; Wydawnictwo Naukowe UMK, 2009.

Glemma, Tadeusz. Historjografja diecezji chełmińskiej aż po rok 1821. Kraków: [s. n.], 1925.

Jasiński, Kazimierz. „Stanisław Kujot (1845-1914)”. In: Działacze Towarzystwa Naukowego w Toruniu 1875-1975, ed. Marian Biskup, 85-179. Warszawa-Poznań: Państwowe Wydawnictwo Naukowe, 1975.

Mross, Henryk. Słownik biograficzny kapłanów diecezji chełmińskiej wyświęconych w latach 1821-1920. Pelplin: Wydawnictwo „Bernardinum”, 1995.

Muzioł, Ryszard. Słownik biograficzny Chetmży i okolic, vol. 2: Proboszczowie i administratorzy parafii rzymskokatolickiej św. Mikołaja Biskupa $w$ Chełmży w latach 1824-2014. Chełmża: Wąbrzeskie Zakłady Graficzne, 2014.

Rozynkowski, Waldemar. Powstanie i rozwój sieci parafialnej w diecezji chełmińskiej w czasach panowania zakonu krzyżackiego. Torun: TNT, 2000.

Rozynkowski, Waldemar. Szkice z dziejów gminy Papowo Biskupie. Toruń-Papowo Biskupie: Stowarzyszenie Rozwoju Gminy Papowo Biskupie, 2014.

Walkusz, Jan. „Gdyby o Polskę pytali...”. Z dziejów duchowieństwa Pomorza $i$ Wielkopolski w XIX i XX wieku. Lublin: Towarzystwo Naukowe KUL, 2004.

Walkusz, Jan. Piórem i słowem. Aktywność literacka polskiego duchowieństwa katolickiego na Pomorzu Nadwiślańskim, Warmii i w Wielkopolsce w latach 1848-1939. Pelplin: Wydawnictwo „Bernardinum”, 2003. 